\title{
Positive Psychology Intervention for Families of Hospitalized Children
}

\author{
Doralúcia Gil da Silva ${ }^{1}$ \\ Claudia Hofheinz Giacomoni²
}

\begin{abstract}
Positive Psychology interventions may benefit families with hospitalized children. This study aimed to evaluate a pilot intervention in positive psychology for parents with hospitalized children with acute health conditions. A quasi-experimental study was conducted with thirty mothers with a mean age of $25.37(S D=7.3)$, most of them with incomplete elementary school and married. A focal intervention was applied in the individual and group modality and a comparison group was carried out. Pre- and post-test evaluations were performed using standardized instruments on subjective well-being, symptoms of depression, anxiety and stress and ways of coping with problems. Data pointed out that in the intervention group, the levels of positive affects and problem-focused coping increased in relation to the comparison group. Likewise, in the individual intervention there was also an increase in problemfocused coping in relation to the comparison group.
\end{abstract}

Keywords: positive psychology, hospitalization, family

\section{Intervenção em Psicologia Positiva para Familiares de Crianças Hospitalizadas}

Resumo: Intervenções em psicologia positiva podem beneficiar famílias com crianças hospitalizadas. Este estudo teve por objetivo avaliar uma intervenção piloto em psicologia positiva para familiares de crianças hospitalizadas com condições agudas de saúde. Foi realizado estudo quase experimental em que participaram 30 mães com média de idade 25,37 ( $D P=7,3)$, a maior parte com Ensino Fundamental incompleto e casadas. A intervenção focal foi aplicada na modalidade individual e grupal e foi realizado grupo de comparação. Foi feita avaliação pré e pós teste por meio de instrumentos padronizados sobre bem-estar subjetivo, sintomas de depressão, ansiedade e estresse e modos de enfrentamento de problemas. Os dados apontaram que na intervenção em grupo aumentaram os níveis de afetos positivos e o enfrentamento com foco no problema em relação ao grupo de comparação. Da mesma forma, na intervenção individual houve aumento do enfrentamento com foco no problema em relação ao grupo de comparação.

Palavras-chave: psicologia positiva, hospitalização, família

\section{Intervención en Psicología Positiva para Familias de Niños Hospitalizados}

Resumen: Las intervenciones en psicología positiva pueden beneficiar a familias con niños hospitalizados. Este artículo tiene por objetivo evaluar una intervención piloto en psicología positiva para familias con niños hospitalizados con enfermedades agudas. Se realizó un estudio cuasi-experimental en el que participaron 30 madres con una media de edad de 25,37 $(D E=7,3)$ en su mayoría con enseñanza primaria incompleta y casadas. La intervención focal se aplicó en la modalidad individual y grupal y se organizaron grupos de comparación. Se realizaron evaluaciones previas y posteriores al test a través de instrumentos estandarizados acerca de bienestar subjetivo, síntomas de depresión, ansiedad y estrés y modos de afrontamiento de problemas. Los resultados señalaron que la intervención en grupo aumentó los niveles de afectos positivos y el afrontamiento con foco en el problema en relación al grupo de comparación.

Palabras clave: psicología positiva, hospitalización, familia

\footnotetext{
${ }^{1}$ Hospital Escola da Universidade Federal de Pelotas, Pelotas-RS, Brazil.

${ }^{2}$ Universidade Federal do Rio Grande do Sul, Porto Alegre-RS, Brazil

Article derived from Doralúcia Gil da Silva's doctoral thesis under the supervision of Cláudia Hofheinz Giacomoni, defended in 2018, in the Graduate Program in Psychology of Universidade Federal do Rio Grande do Sul.

Correspondence address: Doralúcia Gil da Silva. Hospital Escola da Universidade Federal de Pelotas. Rua Prof. Araujo, 538, Pelotas-RS, Brazil. CEP 96.010-610. E-mail: doralu.gil@gmail.com
}

This study aims to evaluate a pilot project of intervention in Positive Psychology (PP) for family members of children hospitalized with acute health conditions. For this, the theoretical intersections between PP and Health Psychology in the hospital context must be considered. The latter aims to study human behavior in health and disease and to understand the psychological variables involved in maintaining health, 
development of diseases, and behaviors associated with diseases (Hong \& Robiner, 2016). One of the approaches is promotion and prevention in health, considering the positive and preserved aspects of health (Mutarelli, 2015). At this point, the theoretical relationships between the two areas that can have repercussions in terms of interventions can be found. Thus, it is considered that it makes sense to implement PP interventions in the hospital context.

PP interventions, in turn, are procedures that aim to increase positive behaviors and thoughts, well-being, and human flourishing (Chaves, Lopez-Gomez, Hervas \& Vazquez, 2017; Hendriks et al., 2019). In fact, empirical studies show that such simple activities promote a significant increase in well-being and alleviate depression symptoms in the short term (Lyubomirsky \& Layous, 2013). Thus, it is worth highlighting and justifying the constructs listed as parameters for the evaluation of this intervention.

Subjective well-being can play a beneficial role in the process of coping with hospitalization for the families, since the longer the experience of this, the more positively people experience their lives, the better they see themselves and others, enjoy greater pleasure in everyday situations and in relationships, and is associated with good health and adaptive functioning (Kern, Waters, Adler \& White, 2015). However, given the stressful conditions of the hospitalization situation, it is common for family members to report symptoms of anxiety, depression, and stress (Muscara et al., 2015). Finally, regarding coping with hospitalization, it is understood that there are a variety of strategies that can be used. This study adopts the perspective of coping strategies (Maia, Sendas, Lopes \& Mendes, 2015; Lazarus \& Folkman, 1984). These are defined as cognitive and behavioral efforts used to deal with internal or external demands that arise in situations of stress. It is an interaction between the individual and the environment in which the person changes behaviors according to the demands that arise. It is important to identify the main coping strategies used by the families, differentiating those that work in the hospital context and those that do not favor them, intervening and guiding them accordingly. Zapata, Bastida, Quiroga, Charra and Leiva (2013) indicate that many caregivers use ineffective strategies, which are associated with worse levels of wellbeing and therefore suggest the need for group interventions that help the family members to optimize their coping skills, enhancing the ones they already have.

Therefore, interventions in PP can benefit the family members who are facing illness and hospitalization of children with acute conditions. These are situations in which there are manifestations of short-term communicable diseases (diseases of the respiratory system, dengue) or short-term infectious diseases (appendicitis), symptoms of infectious conditions (diarrhea, dysentery) or trauma (falls, accidents) (Mendes, 2012; Ministry of Health, 2018). In this sense, they occur in a quite unpredictable manner, on an emergency basis, which can cause high levels of stress and anxiety in the face of the situation.In addition, fewer studies focusing on acute health conditions are produced in relation to the number of studies on the topic of chronic conditions
(Afonso, Gomes \& Araujo, 2015; Moura, Moreira, Menezes, Ferreira \& Gomes, 2017; Palomino-Rodriguez et al., 2015). One hypothesis is that chronic and serious conditions receive more attention from the researchers because these are challenges for the professionals who work with patients and family members with such demands, since they need constant and prolonged care, and present health problems and several complex variables involved in the process (Afonso et al., 2015; Moura et al., 2017; Palomino-Rodriguez et al., 2015). In this sense, theoretical studies and specific interventions for acute conditions are appropriate. Even more so if the patients in these cases are children since, from the developmental point of view, there is a drop in expectations for the family when facing a health problem in the little ones (Moura et al., 2017). In this paper, the term family/family members is used to name and cover the main caregivers of the children and their companions during hospitalization.

It is important to note that this study focuses on hospitals in the Brazilian Unified Health System (Sistema Único de Saúde - SUS), aiming to contribute to an evidence-based and low-cost work proposal in hospital psychology. It is noteworthy that the reality of public health in the country lacks scientifically grounded practices by Psychology professionals and that they also lack in showing effectiveness, efficiency and replicability (Melnik, Souza \& Carvalho, 2014; Pereira \& Veiga, 2014). In addition, this work has the characteristic of being focal, considering that interventions performed only once also demonstrate positive results (Hendriks et al., 2019). Taking into account the literature indications of the effectiveness of group interventions (Zapata et al., 2013), as well as the performance of individual interventions in psychological care in hospitals; the intervention was designed to be applied in both modalities, in addition to conducting comparison groups (Creswell, 2010).

Thus, this study aimed to evaluate a pilot intervention in positive psychology for family members of children hospitalized with acute health conditions. The initial hypotheses were as follows: (a) the intervention carried out in the individual and group modality will increase the levels of subjective well-being, in comparison to the control group; (b) the intervention carried out in the individual and group modality will decrease the levels of anxiety, depression and stress, in comparison to the control group; (c) the intervention carried out in the individual and group modality will produce changes in the coping strategies, although without any hypothesis about what these changes would be; (d) the intervention carried out in the group modality will have a greater effect than the individual intervention (higher levels of subjective well-being and lower levels of anxiety, depression, and stress).

\section{Method}

\section{Participants}

A total of 30 people participated in this study. The sample size was reached due to the end of the time allowed and established by the institution for participant recruitment 
and data collection (June to December) in order to conduct the research. The majority, $86.7 \%$, were consanguineous mothers $(n=26)$, female $(n=29)$, married $80 \%(n=26)$, with a mean age of $M=25.37(S D=7.03)$, and who declared not working $83.3 \%(n=25)$. Eleven individuals participated in the group intervention modality, ten in the individual intervention, and nine were part of the comparison group. The children of the participants in the three groups were mostly male ( $n=7$ in the intervention group; $n=9$ in the individual intervention, and $n=6$ in the comparison group). The mean ages of the children in the groups were $1.08(S D=1.84)$; $1.72(S D=3.30)$, and $0.42(S D=0.58)$ respectively. In each of the three groups, there were five children whose reason for hospitalization was bronchiolitis. The mean length of stay was 1 week and 2 days.

The exclusion criteria were the following: illiterate people, family members of children with serious diseases (cancer, neurological diseases, genetic syndromes, heart diseases, and chronic diseases) and who had been in the hospital for more than a month due to the fact that the severity of the disease and length of stay is significantly associated with increased stress and changes in the coping strategies, either modifying or increasing their variability (Schultze-Lutter, Schimmelmann \& Schmidt, 2016). No participants withdrew from participating during the intervention.

The intervention consisted of a meeting with a mean duration of 2 hours. This framework was designed so as to enable pre- and post- evaluations, considering the mean length of stay observed at the research site (mean of 7 days). The objectives of the activity were to reduce symptoms of anxiety, depression and stress, increase the levels of subjective wellbeing, and provide learning and flexibility in positive coping strategies for hospitalization. To achieve each objective, a different activity was applied, namely: exercise of the Three Good Things (Mongrain \& Anselmo-Matthews, 2012); sharing experiences, social comparison, social support, stress psychoeducation, stress and anxiety management with a relaxation technique; psychoeducation on coping strategies, and learning exercise from the observation of behavior. The intervention protocol was performed according to the TiDier checklist (Hoffman et al., 2014) (Table 1).

Table 1

Description of the Intervention and Replication (TiDier) Checklist

\begin{tabular}{ll}
\hline Item Number & Item \\
\hline Brief name & Positive Psychology Intervention for families of hospitalized children \\
2 & $\begin{array}{l}\text { The study aims to evaluate a pilot intervention for family members of children hospitalized with acute health } \\
\text { conditions. }\end{array}$ \\
What? & $\begin{array}{l}\text { The two interventions - group and individual - included the exercise of the Three Good Things, psychoeducation } \\
\text { on stress, anxiety and stress management using a relaxation technique, and psychoeducation on coping strategies. } \\
\text { The comparison group had an orientation activity on child development. }\end{array}$
\end{tabular}

Who?

4

How?

5

Where?

6

When and how much?

7

Tailoring

8

Modifications

9

How well

10

11
The sessions were conducted by a psychologist with a Master's degree and experience in the area of clinical and health psychology.

The intervention consisted of a session with groups of 3 to 5 participants, lasting approximately 2 hours.

The participants were recruited from the Hospital's Pediatrics unit where the research was conducted.

The intervention consisted of a session conducted on Mondays from $3 \mathrm{pm}$ to $5 \mathrm{pm}$ in the individual and group modalities. The comparison groups were conducted on Fridays.

The intervention was planned to be personalized or adapted according to the content brought by the participants during the sessions.

The intervention adherence or reliability was not assessed.

There were no changes included during the intervention.

The mean number of sessions was 10 for individual interventions, 4 for group interventions, and 3 for comparison groups. Thirty participants completed the program. The reasons for not starting the intervention were not being present at the time of the post-test and the need for medical procedures at the time the intervention was going to be applied. 


\section{Instruments}

Sociodemographic data sheet. Instrument used to collect data such as age, gender, child's family life, information about work, schooling, religion, reason for the child's hospitalization, length of stay, and number of previous hospitalizations.

Subjective Well-Being Scale (SWBS) (Albuquerque \& Tróccoli, 2004). This instrument contains the items related to positive and negative affects and life satisfaction. The psychometric properties were considered adequate in the original study, with the internal consistency indexes, evaluated by a Cronbach's alpha of 0.86 for the total scale, of 0.95 for positive affects, of 0.95 for negative affects, and of 0.90 for life satisfaction. In this study, these indexes were $0.71,0.88,0.95$, and 0.70 respectively.

Depression, Anxiety and Stress Scale (DASS 21) (Vignola \& Tucci, 2014). This instrument has internal consistency indexes considered adequate, assessed by Cronbach's alpha, being 0.92 for the depression subscale, 0.90 for the stress subscale, and 0.86 for the anxiety subscale. In the present study, these indexes were $0.64,0.84$, and 0.82 respectively.

Ways of coping scale (Escala de Modos de Enfrentamento de Problemas, EMEP) (Seidl, Tróccoli \& Zannon, 2001). This instrument contains 45 items that identify four ways of coping in the face of stressful situations: Problem-focused coping strategies, Emotion-focused coping strategies, Religious Practices/Fantasy Thinking, and Search for Social Support. Such factors obtained internal consistency indexes considered adequate, measured by Cronbach's alpha, being 0.84, 081, 0.74 , and 0.70 respectively in the study cited. In the present study, the indexes were $0.90,0.81,0.74$, and 0.66 respectively.

\section{Procedures}

Data collection. The family members who met the inclusion criteria were invited to participate in the study. The objectives of the research were explained, as well as the guarantee of confidentiality, voluntariness and interruption of participation at any time. The participants who agreed to participate signed a free and Informed Consent Form. All the ethical aspects were guaranteed. At the end of data collection, the possibility of applying the intervention to the comparison group was offered. The study was approved by the Ethics Committee of the place where the research was conducted. After accepting to enter the study, the participant filled out the instruments described above. She did not know which group she would be allocated to, only if she would participate individually or in a group. The Hospital's Pediatrics unit consists of two wards with five beds each. Randomly, each week one of the three modalities of the experimental conditions was performed in each ward. For example, in week 1 , the family members from ward " $A$ " were invited to participate in the study as a group intervention. In week 2 , the family members from ward " $B$ " were invited to participate in the study in the modality of individual intervention. Subsequently, the rotation would restart until the time allowed for the research was completed.

The evaluations before and after the intervention were carried out by previously trained undergraduate Psychology students. The groups were previously paired, so that the demographic data and the means of the instruments of the participants in the pre-test were similar in the three conditions. After the application of the instruments, the psychologist responsible for the study proceeded with the intervention. On the following day, the participants filled out the instruments again, with the addition of the intervention evaluation questionnaire, among the individuals who had gone through it. The comparison and intervention groups were conducted in the wards of the hospital alternately during the weeks between June and December, according to the acceptance of participation and to the inclusion and exclusion criteria for the study. The comparison groups received an activity in which the child's health booklet (Ministry of Health, 2018) was used as a guide. Information on child development contained in the material was read and commented on, the family members' questions about past data were answered, and there was room for other questions from the participants. These groups had a mean duration of one hour.

The moments of the group meetings were previously agreed upon with the medical and nursing teams. The mothers were offered the possibility of the children staying in the recreation room accompanied by other professionals of the team. However, some mothers or children refused and preferred that they remained together during the intervention.

Data analysis. As for the data analysis procedures, the assumption of normality, tested using the KolgomorovSmirnov test, was not met. The homogeneity of the variances, assessed through Levene's F and visualization of the boxsplot, was also not met. Thus, non-parametric statistics was used. The Friedman's test was performed to test differences within (intra) each group in all the variables (mean of total Dass, means in the positive affects, negative affects, and life satisfaction subscales, means in focus on the problem, focus on emotion, social support, and religious practices subscales). This analysis did not reveal any statistically significant differences in any variable. The Kruskal Wallis test was used to compare the differences between the three groups in the scores of the instruments. This test showed significant differences. The Mann-Whitney test was used to verify between which pairs of groups there were differences.

\section{Ethical Considerations}

The study was approved by the Ethics Committee of the Medical School of Universidade Federal de Pelotas (Opinion No. 1,973,322 and CAAE No. 64208816.6.0000.5317).

\section{Results}

To verify the effects of the intervention between the groups, the difference variable (delta variable) was 
constructed by subtracting the means of the instruments of the post-test minus the pre-test. With the difference variables of each scale and subscale, the Kruskal-Wallis was used to compare the three groups, which showed significant differences in the positive affects (PA) subscale $(5.51 ; D o F=2 ; p=0.05)$ from the SWBS and in the focus on the problem subscale $(6.89 ; D o F=2 ; p=0.03)$ from the EMEP. Further analysis using Mann-Whitney showed that there was a significant increase in the mean of positive affects in the intervention group vs. the comparison group $(U=21.50 ; z=-2.12 ; p=0.03)$. The analysis also revealed a difference between the intervention group and the comparison group $(U=22 ; z=-2.08 ; p=0.03)$, and between the individual intervention and the comparison group $(U=16 ; z=-2.36 ; p=0.01)$ in the problem-focused coping subscale. Between the group and individual interventions, no significant differences were found. Table 2 shows the results of the analyses.

Table 2

Pre- and Post- Test Values, Confidence Intervals (CI) and Effect Size for Each Group

\begin{tabular}{|c|c|c|c|c|c|c|c|}
\hline Group Intervention & $\begin{array}{l}\text { Pre-test } \\
M(S D) \\
\end{array}$ & $\begin{array}{c}\text { Pre-test } \\
M d\end{array}$ & $\begin{array}{c}\text { 95\% C.I. } \\
\text { Means }\end{array}$ & $\begin{array}{c}\text { Post-test } \\
M(S D)\end{array}$ & $\begin{array}{c}\text { Post-test } \\
M d\end{array}$ & $\begin{array}{c}\text { 95\% C.I. } \\
\text { Means }\end{array}$ & $\begin{array}{l}\text { Effect Size } \\
\text { (Cohen's D) }\end{array}$ \\
\hline Positive Affects & $60.72(12.37)$ & 57.00 & $52.41-69.04$ & 65.36* (12.61) & 63.00 & $56.89-73.83$ & \\
\hline $\begin{array}{l}\text { Confronting with Focus on } \\
\text { the Problem }\end{array}$ & $61.24(14.56)$ & 63.22 & $51.46-71.03$ & $66.30(14.14)$ & 74.27 & $56.79-75.80$ & 0.76 \\
\hline \multicolumn{8}{|l|}{ Individual Intervention } \\
\hline Problem-Focused Coping & $54.91(11.71)$ & 54.75 & $46.52-63.29$ & $\mathbf{5 8 . 4 8 *}(15.00)$ & 62.69 & $47.75-69.21$ & 0.23 \\
\hline \multicolumn{8}{|l|}{ Comparison Group } \\
\hline Positive Affects & $64.11(19.38)$ & 65.00 & $49.21-79.00$ & $59.00 *(16.80)$ & 59.00 & $46.00-71.91$ & 0.46 \\
\hline Problem-Focused Coping & $64.12(14.50)$ & 66.27 & $52.97-75.27$ & $\mathbf{5 5 . 1 9} *(15.24)$ & 60.16 & $43.47-66.91$ & \\
\hline
\end{tabular}

Note. ${ }^{*} p<0.05$.

\section{Discussion}

In general, the results that demonstrated significant differences in the intervention performed in group in relation to the comparison group are in agreement with the indications in the literature that group interventions benefit the family members of hospitalized children (Zapata et al., 2013) and the hypotheses related to the effect of the intervention, regardless of the modality. Specifically, the difference pointed out in the positive affects variable can be directly related to this, since the feeling of welcome and mutual support between peers can promote positive emotions at this moment, despite the stressful situation being experienced (Kern et al., 2015; Zapata et al., 2013). Furthermore, creating a moment of socialization and focusing on the present moment, when concerns are left out, helps to elicit positive affects (Kern et al., 2015).

In addition to the increase in positive affects, there was an increase in coping with a focus on the problem among the participants who undertook the group intervention in relation to the comparison group. This is in line with the idea that perceived social support - which may have been activated in the group intervention - can promote coping strategies and help adapt to stressful changes and moments (Schultze-Lutter et al., 2016). The strategy focused on the problem has the potential to be positive, because it can help mothers to focus on something evaluated as changeable and that, in some way, they can act to help resolve the issue (Hendriks et al., 2019; Lazarus \& Folkman, 1984), reducing the feeling of powerlessness in the face of their children's illness (Muscara et al., 2015; O’Malley, Randell \& Dowd, 2016). In addition, such a strategy can be more effective in reducing emotional tension (Hendriks et al., 2019).

In the same way, the significant difference found between the individual intervention and the group that did not receive it in the problem-focused coping subscale can be understood. Just as in the group form, individual mothers may have had the experience of focusing and trying to modify the changeable stressor and have tension relief. On the other hand, there is a reflection that, in the individual intervention, the participants did not experience support and social reception and, therefore, did not experience positive emotions and well-being that can be associated with group and social activities (SchultzeLutter et al., 2016), as demonstrated in the group intervention. No significant differences were found in the comparison between the intervention performed in groups and individually in any variable. Thus, the hypothesis that the group intervention would have a greater effect than the individual intervention was not confirmed. This result may indicate that the intervention can bring interesting results applied both in group and individual modalities, since the two formats, depending on their particularities, can bring different benefits. In the group modality, according to what has already been described, the participants can experience social support and positive emotions associated with it. However, in the individual modality, the mothers may feel more comfortable to go deeper into some issues without fear of being judged by peers (Schultze-Lutter et al., 2016).

Within the groups there were also no significant differences. Some questions are raised in this regard. Possible intervening factors that may have altered the 
results must be considered. Threats to internal validity may have occurred, such as the testing, in which the pre- and post-test model was used. Doing it once implies the next testing, even more with the same instruments in a short period of time. Similarly, the effect of the history may have influenced the results, since the mothers were also receiving interventions from other health professionals that may have contributed positively to well-being and improved results over the days during hospitalization, which may have confused or added to the effect of the psychological intervention itself. Another element that may have biased in some way the results herein described is the selection, as there were different groups to which people were allocated. Measures were taken to manage and try to get around this issue, such as the previous pairing of the groups through the means of the instruments in the pre-test, the alternate form of selection on the days for recruitment and participation in the research, the moderator and evaluator of the intervention being different individuals.

However, the time between the pre- and post-test cannot be longer due to the short period of hospitalization. This question may have compromised the internal validity of the intervention. However, the aforementioned threat to internal validity is inherent to research studies with quasi-experimental designs in Psychology, since in the psychological field the complexity of the variables involved in processes such as hospitalization is evident. Therefore, it is difficult to establish pure experiments or without some kind of bias (Creswell, 2010). However, these challenges must not serve as a disincentive or impediment to conducting research studies that seek methodological rigor and the levels of evidence recommended by good scientific practices (Melnik et al., 2014).

The hypothesis that the intervention, whether group or individual, would have a positive effect in relation to the group that received no intervention was confirmed. There were significant differences between the group modality and the comparison group and the individual modality and the comparison group in two variables, with effect size from low to medium. Despite the modest results, together, the data found point to some evidence of the effectiveness of the intervention, according to the notes in the literature (Melnik et al., 2014; Pereira \& Veiga, 2014). Thus, this pilot intervention demonstrates the feasibility of being implemented and of having its quality increased. In this sense, new research studies should seek to improve it and conduct it with larger samples, in order to perform more robust statistical analyses and find new evidence. In addition, the results herein found are the outcome of a study that sought to be in accordance with the guidelines of the evidencebased practice (Melnik et al., 2014; Pereira \& Veiga, 2014), considering that the psychological intervention herein presented targets the multi-professional hospital context in the setting of Brazilian Unified Health System. Another aspect that deserves to be highlighted is the positive results of this intervention, which was carried out in a punctual and focal manner. Thus, it is pointed out that professionals and researchers can continue investing, also in brief activities, as these demonstrate benefits (Mongrain \& AnselmoMatthews, 2012). It should be noted that, for being punctual and low cost, they are options to be considered in the contexts of the SUS and of acute health conditions, where the length of hospitalization may be short. In addition, in these conditions, in which the emergency and unpredictable character is demarcated, such unique interventions can be functional in addressing the problem in a punctual and focal manner, similar to the way it arose.

Despite some results in favor of the intervention herein reported, it is worth making some notes about the limitations of this study. It is noted that the interpretation of the data presented refers only to the sample studied with the design used. First, the research was carried out in a hospital in an inland region of the state of Rio Grande do Sul that serves a population with specific sociodemographic characteristics. In the sample, the profile of mothers of babies predominated, aged around 20 years old, married, with low schooling, and housewives. In this sense, other profiles of family members of hospitalized children may have a different use of the intervention than what was presented here. Positive Psychology interventions have a variety of exercises and modalities that can be implemented. For this study, some exercises were listed with indication by the literature that they could be effective to enhance wellbeing (Mongrain \& Anselmo-Matthews, 2012). However, it is important that other formats and another organization of PPIs are used in future studies. For example, other relevant interventions such as the expression of gratitude, the exercise of the best possible selves and counting blessings can be used to increase positive affects (Emmons \& McCullough, 2003). This is because the combination of these activities according to the specific objective of the intervention and the target audience can be made more flexible (Mongrain \& AnselmoMatthews, 2012). Therefore, it is important that the possible combinations are well grounded and empirically tested. Finally, it must also be considered that it is relevant to have more than one trained moderator who applies the activities, in order to mitigate the effects of the nonspecific factors of the interventions in Psychology (Hendriks et al., 2019). This point is important to produce replications and improve the PPIs in an appropriate and well-informed way (Hendriks et al., 2019; Mongrain \& Anselmo-Matthews, 2012).

\section{Referências}

Afonso, S. B. C., Gomes, R., \& Araujo, R. M. M. (2015). Narratives of the parents' experience of children with cystic fibrosis. Interface: Comunicação Saúde Educação, 19(55), 1077-1089. doi: 10.1590/1807-57622014.0569

Albuquerque, A. S., \& Tróccoli, B. T. (2004). Desenvolvimento de uma escala de bem-estar subjetivo [Subjective well-being scale development]. Psicologia: Teoria e Pesquisa, 20(2), 153-164. doi:10.1590/S010237722004000200008 
Chaves, C., Lopez-Gomez, I., Hervas, G., \& Vazquez, C. (2017). A comparative study on the efficacy of a positive psychology intervention and a cognitive behavioral therapy for clinical depression. Cognitive Therapy and Research, 41(3), 417-433. doi:10.1007/s10608-016-9778-9

Creswell, J. W. (2010). Projeto de pesquisa: Métodos qualitativo, quantitativo e misto [Research Project: Qualitative, quantitative and mist methods] (M. F. Lopes, Trans., 3rd ed.). Porto Alegre, RS: Artmed.

Emmons, R. A., \& McCullough, M. E. (2003). Counting blessings versus burdens: An experimental investigation of gratitude and subjective well-being in daily life. Journal of Personality and Social Psychology, 84(2), 377-389. doi:10.1037/0022-3514.84.2.377

Hendriks, T., Warren, M. A., Schotanus-Dijkstra, M., Hassankhan, A., Graafsma, T., Bohlmeijer, E., \& Jong, J. (2019). How weird are positive psychology interventions? A bibliometric analysis of randomized controlled trials on the science of well-being. Journal of Positive Psychology, 14(4), 489-501. doi:10.1080/17439760.2018.1484941

Hoffman, T. C., Glasziou, P. P., Boutron, I., Milne, R., Perera, R., Moher, D., ... Michie, S. (2014). Better reporting interventions: Template for intervention description and replication (TiDier) checklist and guide. BMJ, 348, g1687. doi:10.1136/bmj.g1687

Hong, B. A., \& Robiner, W. N. (2016). Psychologists in academic health centers and medical centers: Being visible, relevant and integral. Journal of Clinical Psychology in Medical Settings, 23(1), 11-20. doi:10.1007/s10880-016-9450-2

Kern, M. L., Waters, L. E., Adler, A., \& White, M. A. (2015). A multidimensional approach to measuring well-being in students: Application of the PERMA framework. Journal of Positive Psychology, 10(3), 262-271. doi:10.1080/174 39760.2014.936962

Lazarus, R. S., \& Folkman, S. (1984). The concept of coping. In Stress, appraisal and coping (pp. 117-139). New York, NY: Springer.

Lyubomirsky, S., \& Layous, K. (2013). How do simple positive activities increase well-being? Current Directions in Psychological Science, 22(1), 57-62. doi:10.1177/0963721412469809

Maia, A., Sendas, S., Lopes, R., \& Mendes, J. M. (2015). A eficácia das estratégias de coping após um evento traumático: Uma revisão sistemática. E-cadernos Ces, 25. doi: $10.4000 /$ eces. 2058

Melnik, Souza, \& Carvalho, M. R. (2014). A importância da prática da psicologia baseada em evidências: aspectos conceituais, níveis de evidência, mitos e resistências [The importance of evidence-based practices in psychology: Conceptual aspects, evidence levels, myths and resistance]. Revista Costarricense de Psicología, 33(2), 79-92.
Mendes, E. V. (2012). O cuidado das condições crônicas na atenção primária à saúde: $O$ imperativo da consolidação da estratégia da saúde da família [The care of chronic conditions in primary health care: The imperative of consolidating the Family health strategy]. Brasília, DF: Organização Pan-Americana da Saúde. Retrieved from http://bvsms.saude.gov. br/bvs/publicacoes/cuidado_condicoes_atencao_ primaria_saude.pdf

Ministério da Saúde. Secretaria de Atenção à Saúde. Departamento de Ações Programáticas Estratégicas. Área Técnica da Saúde da Criança e Aleitamento Materno. (2018). Caderneta de saúde da criança (5th ed.) [Child Health Booklet]. Brasília, DF: Autor. Retrieved from: https://www.saude.gov.br/artigos/823assuntos/saude-para-voce/40777-caderneta-de-saudeda-crianca

Ministério da Saúde. Secretaria de Vigilância em Saúde. Departamento de Vigilância de Doenças e Agravos não Transmissíveis e Promoção da Saúde. (2018). Relatório do III fórum de monitoramento do plano de ações estratégicas para o enfrentamento das doenças crônicas não transmissíveis no Brasil [III Forum for monitoring the strategic action plan for tackling chronic non-communicable diseases in Brasil report]. Brasília, DF: Autor. Retrieved from http://portalarquivos2.saude. gov.br/images/pdf/2018/junho/19/relatorio-iii-forumdent-v-eletronica-13jun18-isbn.pdf

Mongrain, M., \& Anselmo-Matthews, T. (2012). Do positive psychology exercises work? A replication of Seligman et al. (2005). Journal of Clinical Psychology, 68(4), 382-389. doi:10.1002/jclp.21839

Moura, E. C., Moreira, M. C. N., Menezes, L. A., Ferreira, I. A., \& Gomes, R. (2017). Complex chronic conditions in children and adolescents: Hospitalizations in Brazil, 2013. Ciência \& Saúde Coletiva, 22(8), 2727-2734. doi: 10.1590/1413-81232017228.01992016

Muscara, F., Burke, K., McCarthy, M. C., Anderson, V. A., Stephen, J. C., Hearps, S. J., ... Nicholson, J. M. (2015). Parent distress reactions following a serious illness or injury in their child: A protocol paper for the take a breath cohort study. BMC Psychiatry, 15, 153. doi:10.1186/ s12888-015-0519-5

Mutarelli, A. (2015). O serviço de psicologia no hospital: Modelo assistencial de cuidado na busca pela promoção de saúde[Psychologyserviceathospital:Caremodelforhealth promotion]. Revista da SBPH, 18(1), 173-188. Retrieved from http://pepsic.bvsalud.org/scielo.php?script=sci arttext\&pid=S1516-08582015000100009

O’Malley, D. M., Randell, K. A., \& Dowd, M. D. (2016). Family adversity and resilience measures in pediatric acute care settings. Public Health Nursing, 33(1), 3-10. doi:10.1111/phn. 12246 
Otsuka, K., Taguri, M., Dennis, C. L., Wakutani, K., Awano, M., Yamaguchi, T., \& Jimba, M. (2014). Effectiveness of a breastfeeding self-efficacy intervention: Do hospital practices make a difference? Maternal and Child Health Journal, 18(1), 296-306. doi:10.1007/s10995-013-1265-2

Palomino-Rodriguez, A. A., Morales-Munera, O. L., Contreras-Ortiz, J. O., \& Salazar-Braneo, O. F. (2015). Therapeutic compliance in asthma: Is it a problem of great magnitude? Iatreia, 28(4), 400-410. doi: 10.17533/ udea.iatreia.v28n4a05

Pereira, C., \& Veiga, N. (2014). Educação para a saúde baseada em evidências [Evidence-based health education]. Milenium, 46, 107-136.

Seidl, E. M. F., Tróccoli. B. T., \& Zannon, C. M. L. C. (2001). Análise fatorial de uma medida de estratégias de enfrentamento [Factorial analysis of a coping measure]. Psicologia: Teoria e Pesquisa, 17(3), 225-234. doi:10.1590/S0102-37722001000300004

Schultze-Lutter, F., Schimmelmann, B. G., \& Schmidt, S. J. (2016). Resilience, risk, mental health and well-being: Associations and conceptual differences. European Child \& Adolescent Psychiatry, 25(5), 459-466. doi:10.1007/ s00787-016-0851-4

Vignola, R. C. B., \& Tucci, A. M. (2014). Adaptation and validation of the depression, anxiety and stress scale (DASS) to Brazilian Portuguese. Journal of Affective Disorders, 155, 104-109. doi:10.1016/j.jad.2013.10.031

Zapata, A., Bastida, M., Quiroga, A., Charra, S., \& Leiva, J. M. (2013). Evaluación del bienestar psicológico y estrategias de afrontamiento en padres con niños o adolescentes con retraso mental leve. Psiencia: Revista Latinoamericana de Ciencia Psicológica, 5(1), 15-23. doi:10.5872/psiencia/5.1.22
Doralúcia Gil da Silva is a Health Psychologist of the School Hospital of Universidade Federal de Pelotas, Pelotas-RS, Brazil.

Claudia Hofheinz Giacomoni is a Professor of Universidade Federal do Rio Grande do Sul, Porto Alegre-RS, Brazil.

\section{Authors' Contribution:}

All authors made substantial contributions to the conception and design of this study, to data analysis and interpretation, and to the manuscript revision and approval of the final version. All the authors assume public responsibility for content of the manuscript.

Received: Aug. 20, 2019

1st Revision: Oct. 14, 2019

2nd Revision: Feb. 17, 2020

Approved: Apr. 20, 2020

How to cite this article:

Silva, D. G., \& Giacomoni, C. H. (2020). Positive psychology intervention for families of hospitalized children. Paidéia (Ribeirão Preto), 30, e3036.doi:https://doi.org/10.1590/1982-4327e3036 